\title{
Production, fermentation profile, and nutritional quality of silage from corn and soybean intercropping
}

\author{
Produção, perfil fermentativo e valor nutritivo da silagem \\ proveniente do consórcio entre milho e soja
}

\author{
Karolyna Oliveira Marques ${ }^{1 *}$; Adriano Jakelaitis ${ }^{2}$; Kátia Cylene Guimarães ${ }^{2}$; \\ Leandro Spíndola Pereira ${ }^{3}$; Isabella Sichierski Cardoso ${ }^{4}$; Suzete Fernandes Lima ${ }^{1}$
}

\begin{abstract}
Forage seasonality makes farmers use conservation practices. Mixing corn silage and legumes can enhance silage quality and hence animal productivity. Therefore, this study aimed to evaluate yield and quality of silages from intercropping between genetically modified corn and soybean for glyphosate tolerance (RR - Roundup Ready) as a function of plant spatial arrangement, soybean variety, and sowing fertilization methods. Two intercropping arrangements of RR corn and RR soybeans were tested: alternate single rows of corn and soybeans and double corn rows for each soybean row. Treatments were randomized blocks with four replications, arranged in a $2 \times 2+1$ factorial scheme. The first factor was sowing fertilization method (2): only in corn rows or in total area. The second factor was soybean variety (2): medium- and late-cycle genotypes, and an additional treatment of corn monoculture. After harvest, forage material was analyzed for agronomic characteristics and then ensiled for 60 days. Thereafter, bromatological composition, fermentation profile, and losses were analyzed during silage fermentation process. No differences were observed among treatments for total silage production. Overall, silage from intercropping treatments showed higher levels of hemicellulose, total digestible nutrients, crude protein, and ether extract, thus improving silage quality. However, lower contents of dry matter, acid detergent fiber, and cellulose were also observed in silage from intercropped treatments. In short, adding soybeans to silage can improve final roughage, reducing costs of protein and energy supplements.
\end{abstract}

Key words: GM crops. Glycine max. Silage quality. Zea mays.

\section{Resumo}

A sazonalidade na produção das plantas forrageiras impõe aos produtores o uso de práticas de conservação de forragem. A silagem de milho com leguminosas pode aumentar a qualidade e resultar em maior produtividade animal. Portanto, objetivou-se avaliar a produtividade e a qualidade da silagem do consórcio entre as culturas de milho e soja geneticamente modificadas para tolerância ao herbicida glifosato (RR - Roundup Ready) em função do arranjo espacial das plantas, variedades de soja e adubação de semeadura. Foram realizados dois ensaios com consórcio entre milho RR e soja RR, sendo em arranjo simples (uma linha de milho alternada com uma linha de soja) e outro em arranjo duplo

\footnotetext{
${ }^{1}$ Discentes do Curso de Doutorado do Programa de Pós-Graduação em Ciências Agrárias - Agronomia, Instituto Federal de Educação, Ciência e Tecnologia Goiano, IFGoiano, Rio Verde, GO, Brasil. E-mail: karol-mq@hotmail.com; suzete.lima@, yahoo.com.br

2 Profs., IFGoiano, Rio Verde, GO, Brasil. E-mail: ajakelaitis@yahoo.com.br; katia.guimaraes@ifgoiano.edu.br

3 Discente do Curso de Bacharel em Agronomia, IFGoiano, Rio Verde, GO, Brasil. E-mail: leandrop629@gmail.com

4 Discente do Curso de Mestrado do Programa de Pós-Graduação em Ciências Agrárias, Agronomia, Instituto Federal de Educação, Ciência e Tecnologia Goiano, IFGoiano, Rio Verde, GO, Brasil. E-mail: isabellacardoso-rv@hotmail.com

* Author for correspondence
} 
(duas linhas de milho alternada com uma linha de soja). Os tratamentos foram delineados em blocos ao acaso em esquema fatorial $2 \times 2+1$, com quatro repetições. $\mathrm{O}$ primeiro fator foi constituído de duas modalidades de adubação de semeadura na linha: somente no milho, omitindo a soja; e em área total; o segundo fator a duas variedades de soja: de ciclo médio e tardio. O tratamento adicional correspondeu ao monocultivo de milho. Após colheita do material foi analisado suas características agronômicas, depois o material foi ensilado por 60 dias e realizadas as análises bromatológicas, fermentativas e de perdas durante o processo de fermentação da silagem. Não foram observadas diferenças entre tratamentos para a produção total de silagem. De forma geral, a silagem oriunda dos consórcios apresentou maiores valores para os teores de hemicelulose, nutrientes digestíveis totais, proteína bruta e extrato etéreo beneficiando a qualidade da silagem produzida. Por outro lado, foram observados menores valores percentuais de matéria seca, de fibra em detergente ácido e celulose. Em síntese, a soja pode auxiliar no resultado final do volumoso, diminuindo gastos com suplementação proteica ou uso de suplementos energéticos.

Palavras-chave: Culturas geneticamente modificadas. Glycine max. Qualidade de silagem. Zea mays.

\section{Introduction}

Intercropping is a widespread practice among farms, especially in areas unsuitable for mechanization or spatially limited farms. In croplivestock integration systems, intercropping between annual and forage crops have been used for pasture formation or recovery (BALBINO et al., 2011; PARIZ et al., 2011). The advantages of using such technique include increased land-use efficiency, less total loss risks, improved soil conservation, and animal diet diversification (BARCELLOS et al., 2008).

Herd feeding makes up the largest part of livestock costs. In this sense, many efforts have been made to find feedstuffs of better quality, nutritional value, and lower costs, thereby increasing profitability in agrosystems. A promising option is to associate grasses and legumes - e.g., silage from soybeans intercropped with forages (GOBETTI et al., 2011).

Ensiling is one of the most used methods to conserve fresh forage worldwide, as it has contributed to increasing livestock productivity and profitability (VIEIRA et al., 2011). In Brazil, corn is commonly used as silage due to its ease of cropping and conservation, cultivars adapted to different regions of the country, and produced silage quality, as well as being excellent for animal consumption, improving beef and dairy productions (DEMINICIS et al., 2009). Corn silage, however, has low protein content, which limits its exclusive use for animals with high nutritional requirements. In contrast, alternative sources of legume forages can be used to increase the protein content of feeds, such as soybeans (SILVA et al., 2015).

Grass and soybean intercropping systems have not yet been extensively inserted into the livestock chain due to issues related to agricultural machinery, costs, crop cultivars, and weed management Meanwhile, genetically modified soybeans and corn plants for glyphosate tolerance (Roundup Ready RR) have emerged and brought new possibilities to optimize intercropping between corn and soybeans. Weed management in RR corn and RR soybeans is practical and efficient, besides adding advantages such as easy weed control, crop management flexibility, and cost saving (CORREIA; DURIGAN, 2010).

The areas of Cerrado (savannah) in Brazil stand out country-wise in terms of corn, soybean, and livestock productions (DOMINGUES; BERMANN, 2012). In such fields, there is a predominance of soybean cropping during the growing season and corn in succession during the off-season. Added to this is the use of RR soybean and corn crops, which allows gains in silage biomass and quality due to soybean inclusion as companion crop into corn silage production systems. However, to validate this method, several agronomic demands must be fulfilled such as defining plant spatial arrangement, fertilization management, used varieties, mainly for 
soybeans, which should fit an intercropping system.

Therefore, this study aimed to evaluate the performance of different soybean varieties, sowing fertilization managements, and spatial planting arrangements in an intercropping between RR corn and RR soybeans in terms of silage yield and quality.

\section{Material and Methods}

The study was conducted between October 2015 and February 2016 at the Federal Institute of Goiás (Instituto Federal Goiano) in Rio Verde city, Goiás State - Brazil (1748'67' S, 5054'18” W, and 754-m altitude). Prior to the experiment, the local soil (a Red Latosol - Oxisol) was chemically analyzed using samples from the $0-20 \mathrm{~cm}$ depth layer. The results were as follows: $\mathrm{pH}$ (in $\left.\mathrm{CaCl}_{2}\right)=$ 5.30, $\mathrm{P}=13.1 \mathrm{mg} \mathrm{dm}^{-3}, \mathrm{~K}=181 \mathrm{mg} \mathrm{dm}^{-3}, \mathrm{Ca}=4.64$ $\mathrm{cmol}_{\mathrm{c}} \mathrm{dm}^{-3}, \mathrm{Mg}=2.50 \mathrm{cmolc} \mathrm{dm}^{-3}$, and $\mathrm{Al}=0.04$ $\mathrm{cmol}_{\mathrm{c}} \mathrm{dm}^{-3}$. The contents of $\mathrm{Ca}, \mathrm{Mg}, \mathrm{Al}, \mathrm{P}$, and $\mathrm{K}$ were determined according to EMBRAPA (1997), wherein $\mathrm{Ca}, \mathrm{Mg}$, and $\mathrm{Al}$ were extracted by $1 \mathrm{~mol}$ $\mathrm{L}^{-1} \mathrm{KCl}$, and $\mathrm{P}$ and $\mathrm{K}$ by $0.05 \mathrm{~mol} \mathrm{~L}^{-1} \mathrm{HCl}+0.0125$ mol L-1 $\mathrm{H}_{2} \mathrm{SO}^{4}$ (Mehlich-1). Moreover, the chemical analyses showed the following results: $\mathrm{OM}=3.20 \mathrm{~g}$ $\mathrm{dm}^{-3}, \mathrm{~V} \%=62.80, \mathrm{Cu}=2.3 \mathrm{mg} \mathrm{dm}^{-3}, \mathrm{Fe}=13 \mathrm{mg}$ $\mathrm{dm}^{-3}, \mathrm{Mn}=59.7 \mathrm{mg} \mathrm{dm}^{-3}, \mathrm{Zn}=4.5 \mathrm{mg} \mathrm{dm}^{-3}, \mathrm{CEC}$ $=12.1 \mathrm{cmol}_{\mathrm{c}} \mathrm{dm}^{-3}$ (EMBRAPA, 1997). A grain-size analysis was also performed, which showed clay, silt, and sand contents of 645, 100, and $255 \mathrm{~g} \mathrm{~kg}^{-1}$ soil, respectively. Figure 1 displays climate data for the studied period.

Figure 1. Monthly means for rainfall, maximum and minimum temperatures, and relative humidity (RH) from October 2015 to February 2016 in Rio Verde - GO (Brazil).

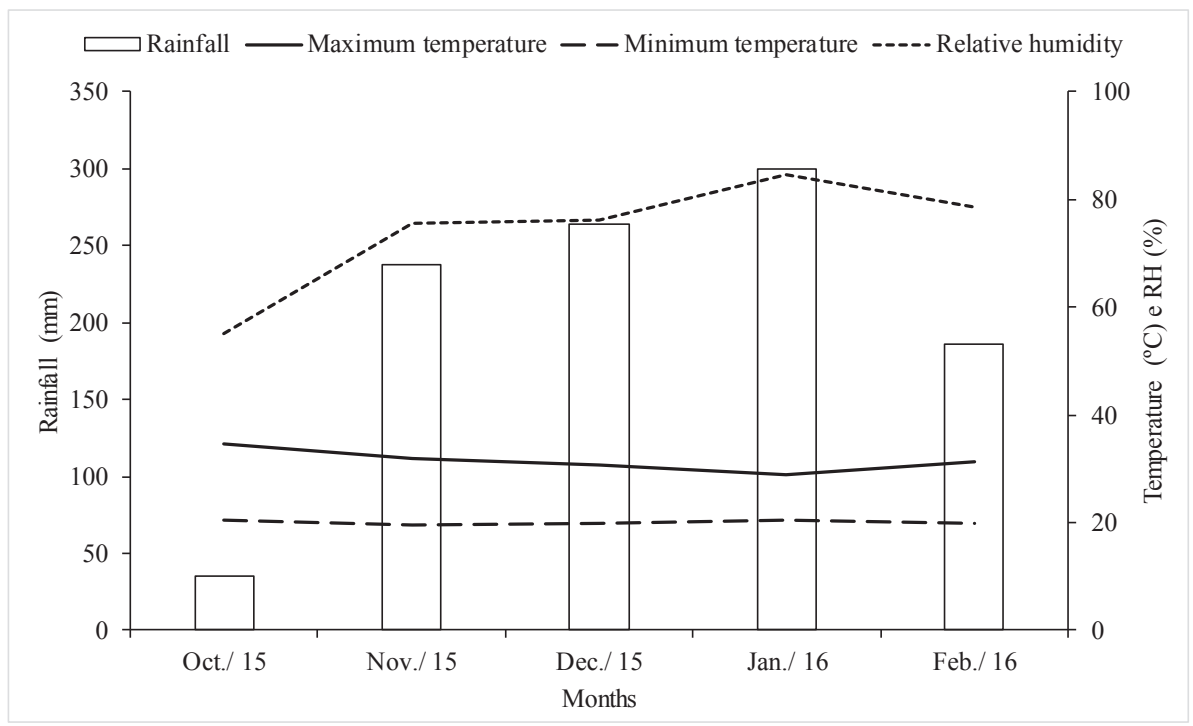

Two trials were carried out simultaneously. Trial 1 was characterized by single corn rows interspersed with single soybean rows, all spaced $1.0 \mathrm{~m}$ apart, corn rows had 6 plants $\mathrm{m}^{-1}$ and soybean rows 20 plants $\mathrm{m}^{-1}$. Trial 2 comprised double corn rows interspersed with single soybean rows, all spaced $0.5 \mathrm{~m}$ apart, corn rows had 4.5 plants $\mathrm{m}^{-1}$ and soybean rows 20 plants $\mathrm{m}^{-1}$.
Both trials were carried out in randomized block design, with treatments arranged in a $2 \times 2+1$ factorial scheme and four replications. The first factor consisted of two in-row sowing fertilization managements: only in corn (CF) neglecting soybeans, and in total area (TF). The second factor consisted of two soybean varieties intercropped with corn: one medium-cycle of 105 days (M7110 IPRO, 
Monsoy $\left.^{\circledR}\right)$, maturity group $6.8(\mathrm{MCV})$; and another late-cycle of 117 days (M7739 IPRO, Monsoy $\left.{ }^{\circledR}\right)$, maturation group 7.7 (LCV). Corn monoculture (CM) was an additional treatment (control). Each experimental plot was six meters wide and six meters long. Blocks and plots were spaced $1.0 \mathrm{~m}$ apart. For evaluation, border rows and $0.5 \mathrm{~m}$ of all rows at each plot end were excluded.

The corn hybrid used was 30F53 YHR (Pionner ${ }^{\circledR}$ ), with a plant population of 60,000 plants $\mathrm{ha}^{-1}$. Sowing fertilization was carried out with $100 \mathrm{~kg} \mathrm{ha}^{-1} \mathrm{P}_{2} \mathrm{O}_{5}, 70$ $\mathrm{kg} \mathrm{ha}^{-1} \mathrm{~K}_{2} \mathrm{O}$, and $20 \mathrm{~kg} \mathrm{ha}^{-1} \mathrm{~N}$ (SOUSA; LOBATO, 2004). Topdressing of single and intercropped corn was performed using $120 \mathrm{~kg} \mathrm{ha}^{-1} \mathrm{~N}$ applied in corn rows at the V5 stage (SOUSA; LOBATO, 2004). Seeds of soybean varieties were inoculated with Bradyrhizobium spp. and treated with imidacloprid + thiodicarb $\left(\mathrm{CropStar}^{\mathbb{B}}\right)$, following the manufacturerss recommendation. In both trials, weed was controlled by spraying glyphosate (Roundup 480 ${ }^{\circledR}$ ) 20 days after corn emergence (DAE) at a dose of 2.0 L c.p. ha ${ }^{-1}$. Moreover, chlorpyrifos (Lorsban $480 \mathrm{BR}^{\circledR}$ ) at $600 \mathrm{~mL}$ c.p. ha $^{-1}$ at $30 \mathrm{DAE}$ and lambda-cyhalothrin (Karate 50 $\mathrm{EC} \circledast)$ at $150 \mathrm{~mL}$ c.p. $\mathrm{ha}^{-1}$ at $47 \mathrm{DAE}$ were sprayed for caterpillar and bug controls, as well as a tankmix of pyraclostrobin + epoxiconazole $\left(\right.$ Opera $\left.^{\circledR}\right)$ at $600 \mathrm{~mL}$ c.p. ha $^{-1}$ at $55 \mathrm{DAE}$ for rust control.
Plants were harvested when corn grains were half the milky line. Both corn and soybean were harvested within the useful area and weighed for fresh mass, then chopped with a stationary shredder. Silage was stored in experimental silos, made of PVC tubes ( $0.4 \mathrm{~m}$ long and $0.1 \mathrm{~m}$ wide). Inside each silo, we placed $500 \mathrm{~g}$ sand dried in a forced ventilation oven for total moisture removal, so that effluent losses could be quantified. Samples of soybean and corn plants from each treatment were chopped into about 2-cm particle size, and ensiled in 10-cm compacted layers.

The silos were closed, sealed, and stored for 60 days. After fermentation, they were opened, and the forage material removed was homogenized. From each silo was removed an aliquot of $500 \mathrm{~g}$ silage, which was dried in a forced ventilation oven at $55 \pm 5{ }^{\circ} \mathrm{C}$, for further dry mass weighing. After drying, these samples were ground in Willey mills for bromatological composition analysis.

Bromatological variables measured (Table 1) were: lignin by method proposed by Van Soest \& Robertson (1985); neutral detergent fiber (NDF) by method of Mertens (2002); and dry matter (DM), ether extract (EE), mineral material (MM), acid detergent fiber (ADF), crude protein (CP), and fermentation $\mathrm{pH}$ according to procedures described in AOAC (1990). Effluent (EL) and gaseous (GL) losses were analyzed according to the Jobim et al. (2007).

Table 1. Bromatological analysis of silages for dry matter (DM), acid detergent fiber (ADF), neutral detergent fiber (NDF), lignin (LIG), mineral material (MM), crude protein (CP), ether extract (EE), and in vitro digestibility of dry matter (IVDDM) as a function of treatments in both trials.

\begin{tabular}{|c|c|c|c|c|c|c|c|c|}
\hline \multicolumn{9}{|c|}{ Trial 1: Intercropping under single row system alternating between RR corn and RR soybean } \\
\hline \multirow{2}{*}{ Treatments* } & DM & ADF & NDF & LIG & MM & $\mathrm{CP}$ & $\mathrm{EE}$ & IVDDM \\
\hline & \multicolumn{8}{|c|}{ 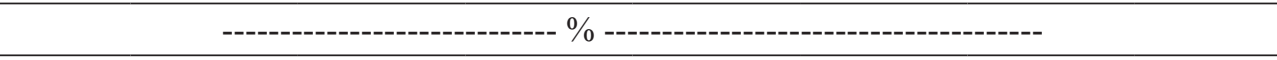 } \\
\hline $\mathrm{CF}-\mathrm{MCV}$ & 28,19 & 28,12 & 51,18 & 10,49 & 5,23 & 9,21 & 5,20 & 59,44 \\
\hline CF - LCV & 30,31 & 25,22 & 54,02 & 9,85 & 5,09 & 8,38 & 6,68 & 61,12 \\
\hline $\mathrm{TF}-\mathrm{MCV}$ & 29,93 & 26,55 & 48,25 & 9,93 & 4,98 & 10,08 & 6,25 & 61,31 \\
\hline TF - LCV & 30,52 & 25,81 & 50,43 & 9,64 & 6,05 & 9,99 & 5,74 & 56,87 \\
\hline $\mathrm{CM}$ & 36,24 & 30,01 & 49,80 & 8,78 & 3,42 & 8,15 & 3,02 & 57,65 \\
\hline
\end{tabular}

continue 
continuation

Trial 2: Intercropping under a system of double row of RR corn alternated with one RR soybean row

\begin{tabular}{lcccccccc}
\hline CF - MCV & 29,16 & 29,45 & 56,12 & 10,71 & 6,55 & 9,93 & 4,06 & 57,14 \\
CF - LCV & 29,98 & 27,42 & 56,23 & 12,46 & 6,31 & 11,05 & 5,05 & 59,42 \\
TF - MCV & 31,23 & 26,98 & 49,95 & 11,32 & 5,42 & 11,47 & 4,99 & 59,11 \\
TF - LCV & 31,47 & 27,82 & 57,38 & 9,44 & 6,17 & 10,81 & 6,08 & 58,73 \\
CM & 38,35 & 31,18 & 54,09 & 9,23 & 4,28 & 7,88 & 2,96 & 59,96 \\
\hline
\end{tabular}

*TF - fertilization in total area; CF - fertilization only in corn rows; MCV - medium-cycle soybean variety; LCV - late-cycle soybean variety; $\mathrm{CM}$ - corn monoculture.

In vitro digestibility of DM (IVDDM) was assessed by method described by Tilley and Terry (1963), using a ruminal fermenter (DAISY II), following method in the user manual of ANKOM ${ }^{\circledR}$ Technology equipment, provided by the manufacturer. Total digestible nutrients (TDN) were estimated by the following equation: [TDN\% $=87.84-(0.70 \mathrm{x}$ ADF $)]$, as suggested by Bolsen et al. (1996).

Results were subjected to variance analysis and means compared by the Tukey and Dunnett's tests if needed. For the Dunnett's test, silage from corn monoculture was used as control. The significance level adopted was 5\%. All statistical analyses were performed using the ASSISTAT software v.7.7 Beta (SILVA; AZEVEDO, 2016).

\section{Results and Discussion}

Total ensiled fresh mass had no increase when soybean was used as a companion crop for corn (Table 2). Regardless of soybean variety or sowing fertilization management, the spatial arrangement using single corn rows interspersed with one soybean row (trial 1) promoted mean increases in the total fresh mass of $5.1 \%$ and $94.9 \%$ due to soybeans and corn, respectively. Likewise, the spatial arrangement using double corn rows alternated with single soybean rows (trial 2) also promoted mean increments $3.6 \%$ and $96.4 \%$ due to soybeans and corn.

Table 2. Total (TFM), corn (CFM), and soybean (SFM) fresh matter production in intercropping and monoculture $(\mathrm{CM})$ as a function of treatments: CF - fertilization only in corn rows; TF - fertilization in total area; MCV - mediumcycle soybean variety; and LCV - late-cycle soybean variety.

\begin{tabular}{|c|c|c|c|c|c|c|}
\hline \multirow{2}{*}{ Treatments } & \multicolumn{3}{|c|}{${ }^{1 /}$ Trial 1} & \multicolumn{3}{|c|}{ Trial 2} \\
\hline & $\mathrm{MCV}$ & LCV & Average & VM & VT & Average \\
\hline \multicolumn{7}{|c|}{ TFM $\left(\mathrm{kg} \mathrm{ha}^{-1}\right)^{\mathrm{ns}}$} \\
\hline $\mathrm{CF}$ & $44.699,66$ & $42.055,20$ & $43.377,43$ & $36.188,53$ & $37.044,09$ & $36.616,31$ \\
\hline $\mathrm{TF}$ & $36.944,09$ & $30.666,31$ & $33.805,20$ & $41.282,98$ & $43.282,98$ & $42.282,98$ \\
\hline Average & $40.821,88$ & $36.360,76$ & -- & $38.735,76$ & $40.163,54$ & -- \\
\hline $\mathrm{CM}$ & \multicolumn{2}{|c|}{$42.371,86$} & -- & \multicolumn{2}{|c|}{$35.549,65$} & -- \\
\hline CV (\%) & \multicolumn{3}{|c|}{23,84} & \multicolumn{3}{|c|}{9,92} \\
\hline
\end{tabular}

continue 
continuation

\begin{tabular}{|c|c|c|c|c|c|c|}
\hline \multicolumn{7}{|c|}{ CFM $\left(\mathrm{kg} \mathrm{ha}^{-1}\right)^{\mathrm{ns}}$} \\
\hline $\mathrm{CF}$ & $42.400,22$ & $39.795,22$ & $32.118,74$ & $34.820,10$ & $35.391,58$ & $35.105,84$ \\
\hline $\mathrm{TF}$ & $35.239,24$ & $28.998,25$ & $41.097,72$ & $39.882,71$ & $42.096,71$ & $40.989,71$ \\
\hline Average & $38.819,73$ & $34.396,73$ & -- & $37.351,40$ & $38.744,14$ & -- \\
\hline MT & \multicolumn{2}{|c|}{$41.937,97$} & -- & \multicolumn{2}{|c|}{$34.879,78$} & -- \\
\hline CV (\%) & \multicolumn{3}{|c|}{24,65} & \multicolumn{3}{|c|}{10,39} \\
\hline \multicolumn{7}{|c|}{ SFM $\left(\mathrm{kg} \mathrm{ha}^{-1}\right)^{\mathrm{ns}}$} \\
\hline $\mathrm{CF}$ & $2.299,43$ & $2.259,97$ & $2.279,70$ & 1.368 .42 & $1.652,50$ & $1.510,46$ \\
\hline $\mathrm{TF}$ & $1.704,84$ & $1.668,06$ & $1.686,45$ & $1.400,27$ & 1.186 .27 & $1.293,27$ \\
\hline Average & $2.002,13$ & $1.964,01$ & -- & $1.277,34$ & $1.526,38$ & -- \\
\hline CV (\%) & & 24,19 & & & 32,05 & \\
\hline
\end{tabular}

$\mathrm{CM}$ - corn monoculture. ns - non-significant by the Tukey's test $(\mathrm{p}<0.05) .{ }^{1 /}$ Trial 1: Intercropping under single row system alternating between RR corn and RR soybean. Trial 2: Intercropping under a system of double row of RR corn alternated with one RR soybean row.

When studying soybean varieties (Doko, Ocepar, Dourados, and Cristalina) intercropped with corn under different row arrangements (one corn row + one soybean row and one corn row + two soybean rows), Lempp et al. (2000) found differences in silage production only in the second year, wherein treatments using Doko variety showed a reduction in soybean participation for total silage yield compared to corn. In the first year, the same authors observed no differences among treatments, and the results were similar to those obtained in our study. As corn is a large $\mathrm{C} 4$ plant, it has greater competitive advantage and space occupation over soybeans. Also, soybeans may have benefitted corn through biological nitrogen fixation (BNF). It is known that the use of legumes in intercropping systems can contribute to the amount of forage produced as a function of BNF (ZIMMER et al., 2012).

Soybean addition into ensiled mass promoted bromatological changes in final silage (Table 3 ). This resulted in a decline in ADF contents when compared to exclusive corn silage. However, no interaction was observed between soybean varieties and sowing fertilization methods, ADF contents were $30 \%$ below the desirable values $(<32 \%)$ for silages (NEUMANN et al., 2014).
Both trials presented interactions between fertilization methods and soybean varieties for NDF contents, mainly for total area sowing fertilization, both in soybean and corn. However, medium-cycle soybean had the lowest NDF contents (Table 3). In single-row arrangement alternating corn and soybean, NDF contents were lower than those of corn monoculture (Table 2). The NDF indicates the roughage fibrous fraction amount and the lower the NDF content, better is the silage quality and higher is the DM intake, especially if below 50\% for corn silage (MORAES et al., 2008). However, in our study, contents were above $50 \%$, regardless of treatments (Table 3).

No significant interaction was found between tested factors for lignin content, but soybean addition in single-row treatments (trial 1) increased such levels compared to standard corn silage (Table 3 ). The soybean seed coat is lignin-rich, which might have increased this polymer content in silages (CARVALHO et al., 2015), as soybean participation in ensiled mass was higher in trial 1 than was in trial 2 (Table 2).

For hemicellulose contents, a significant interaction was observed between sowing fertilization method and soybean variety in both 
trials (Table 3). Particularly, increments were higher with soybean insertion into intercropping, except for total area fertilization and medium-cycle soybean variety, which presented smaller contents, similar to those of corn monoculture (Table 3). Regardless of the fertilization method, late-cycle soybeans improved silage quality by increasing hemicellulose contents. This is a highly digestible fiber that rapidly degrades into fatty acids, which are essential for ruminant metabolism (GOMES et al., 2007).

In both spatial arrangements, soybean addition led to decreases in cellulose contents of silages, which were lower than those of corn exclusive silage (Table 3). However, no interaction effects between varieties and fertilization forms were observed for this parameter (Table 3 ).
For EL, GL, pH, and IVDDM, no significant interactions were observed among treatments (Table 4). Treatments in trial 1 showed EL values above those of corn monoculture if compared to trial 2. Also, in this trial, treatments using mediumcycle variety with fertilization applied in corn rows only showed EL higher than did corn monoculture. Such an outcome may be associated with increased soybean participation to the total fresh mass of treatments in trial 1 (Table 2), which may have contributed to higher silage moisture contents. Higher moisture content in soybean silage implies undesirable risks of fermentation by microorganisms such as fungi and yeast (SANTOS et al., 2008).

Table 3. Percentages of acid detergent fiber (ADF), neutral detergent fiber (NDF), lignin (LIG), hemicellulose (HEM), cellulose (CEL) in silages from soybean and corn intercropping and from corn monoculture as a function of treatments: CF - fertilization only in corn rows; TF - fertilization in total area; MCV - medium-cycle soybean variety; LCV - latecycle soybean variety in both trials.

\begin{tabular}{|c|c|c|c|c|c|c|}
\hline \multirow{2}{*}{ Treatments } & \multicolumn{3}{|c|}{${ }^{1 /}$ Trial 1} & \multicolumn{3}{|c|}{ Trial 2} \\
\hline & $\mathrm{MCV}$ & LCV & Average & $\mathrm{MCV}$ & LCV & Average \\
\hline \multicolumn{7}{|c|}{$\mathrm{ADF}(\%)$} \\
\hline $\mathrm{CF}$ & $25,53-$ & $24,79-$ & 25,16 & $25,93-$ & $26,89-$ & 26,41 \\
\hline TF & $24,44-$ & $24,24-$ & 24,34 & $26,41-$ & $25,84-$ & 25,67 \\
\hline Average & 24,98 & 24,51 & -- & 26,17 & 26,41 & -- \\
\hline $\mathrm{CM}$ & \multicolumn{2}{|c|}{28,19} & -- & \multicolumn{2}{|c|}{29,61} & -- \\
\hline $\mathrm{CV}(\%)$ & \multicolumn{3}{|c|}{3,65} & \multicolumn{3}{|c|}{4,62} \\
\hline \multicolumn{7}{|c|}{ NDF (\%) } \\
\hline $\mathrm{CF}$ & $55,49 \mathrm{aA}$ & $55,15 \mathrm{aA}$ & 55,32 & $57,39 \mathrm{aA}$ & $58,48 \mathrm{aA}$ & 57,93 \\
\hline $\mathrm{TF}$ & $49,92 \mathrm{bB}-$ & $54,04 \mathrm{aA}$ & 51,98 & $52,36 \mathrm{bB}$ & $58,54 \mathrm{aA}$ & 55,45 \\
\hline Average & 52,70 & 54,59 & -- & 54,87 & 58,51 & -- \\
\hline $\mathrm{CM}$ & \multicolumn{2}{|c|}{53,52} & -- & \multicolumn{2}{|c|}{55,44} & -- \\
\hline $\mathrm{CV}(\%)$ & \multicolumn{3}{|c|}{2,07} & \multicolumn{3}{|c|}{3,16} \\
\hline \multicolumn{7}{|c|}{ LIG (\%) } \\
\hline $\mathrm{CF}$ & $8,62+$ & $8,18+$ & 8,40 & 7,92 & $8,38+$ & 8,15 \\
\hline $\mathrm{TF}$ & $9,09+$ & $8,95+$ & 9,02 & 7,53 & 7,58 & 7,55 \\
\hline Average & 8,85 & 8,56 & -- & 7,72 & 7,98 & -- \\
\hline $\mathrm{CM}$ & \multicolumn{2}{|c|}{5,63} & -- & \multicolumn{2}{|c|}{6,94} & -- \\
\hline CV $(\%)$ & \multicolumn{3}{|c|}{3,86} & \multicolumn{3}{|c|}{13,32} \\
\hline
\end{tabular}


continuation

\begin{tabular}{|c|c|c|c|c|c|c|}
\hline \multicolumn{7}{|c|}{ HEM (\%) } \\
\hline $\mathrm{CF}$ & $29,96 \mathrm{aA}+$ & $30,36 \mathrm{aA}+$ & 30,16 & $31,45 \mathrm{aA}+$ & $31,59 \mathrm{aA}+$ & 31,52 \\
\hline $\mathrm{TF}$ & $24,58 \mathrm{bB}$ & $29,80 \mathrm{aA}+$ & 27,19 & $25,95 \mathrm{bB}$ & $32,62 \mathrm{aA}+$ & 29,28 \\
\hline Average & 27,27 & 30,08 & -- & 28,70 & 32,10 & -- \\
\hline $\mathrm{CM}$ & \multicolumn{2}{|c|}{25,33} & -- & \multicolumn{2}{|c|}{25,82} & -- \\
\hline CV $(\%)$ & \multicolumn{3}{|c|}{5,86} & \multicolumn{3}{|c|}{5,00} \\
\hline \multicolumn{7}{|c|}{ CEL (\%) } \\
\hline $\mathrm{CF}$ & $16,91-$ & $16,60-$ & 16,75 & $18,01-$ & $18,50-$ & 18,25 \\
\hline $\mathrm{TF}$ & $15,35-$ & $15,29-$ & 15,32 & $18,88-$ & $18,34-$ & 18,61 \\
\hline Average & 16,13 & 15,94 & -- & 18,44 & 18,42 & -- \\
\hline $\mathrm{CM}$ & \multicolumn{2}{|c|}{22,55} & -- & \multicolumn{2}{|c|}{22,67} & -- \\
\hline CV (\%) & \multicolumn{3}{|c|}{6,13} & \multicolumn{3}{|c|}{6,01} \\
\hline
\end{tabular}

$\mathrm{CM}$ - corn monoculture. + or - stand respectively for means above or below the comparative control (CM) by the Dunnett's test $(p<0.05)$. Means followed by different lowercase letters within columns and uppercase letters within rows are statistically different by the Tukey's test $(\mathrm{p}<0.05) .{ }^{1 /}$ Trial 1 : Intercropping under single row system alternating between RR corn and RR soybean. Trial 2: Intercropping under a system of double row of RR corn alternated with one RR soybean row.

In silages from both trials, GL values were higher compared to exclusive corn silage for treatments including fertilization in corn row only and use of medium-cycle soybean variety (Table
4). Such losses are closely related to DM content in the treatment, which was lower and had a higher $\mathrm{pH}$ value (Table 4).

Table 4. Mean values of effluent losses (EL), gaseous losses (GL), fermentation $\mathrm{pH}$, and in vitro digestibility of dry matter (IVDDM) of silages from soybean and corn intercropping and from corn monoculture as a function of treatments: CF - fertilization only in corn rows; TF - fertilization in total area; MCV - medium-cycle soybean variety; $\mathrm{LCV}$ - late-cycle soybean variety in both trials.

\begin{tabular}{|c|c|c|c|c|c|c|}
\hline \multirow{2}{*}{ Treatments } & \multicolumn{3}{|c|}{${ }^{1 /}$ Trial 1} & \multicolumn{3}{|c|}{ Trial 2} \\
\hline & MCV & $\mathrm{LCV}$ & Average & MCV & LCV & Average \\
\hline \multicolumn{7}{|c|}{ EL \% } \\
\hline $\mathrm{CF}$ & $6,73+$ & $6,42+$ & 6,57 & $5,77+$ & 5,07 & 5,42 \\
\hline $\mathrm{TF}$ & 5,71 & $6,36+$ & 6,03 & 4,52 & 4,96 & 4,74 \\
\hline Average & 6,22 & 6,39 & -- & 5,14 & 5,01 & -- \\
\hline $\mathrm{CM}$ & \multicolumn{2}{|c|}{5,22} & -- & \multicolumn{2}{|c|}{4,00} & -- \\
\hline CV $(\%)$ & \multicolumn{3}{|c|}{16,70} & \multicolumn{3}{|c|}{13,86} \\
\hline \multicolumn{7}{|c|}{ GL\% } \\
\hline $\mathrm{CF}$ & $4,58+$ & 4,18 & 4,38 & $4,62+$ & 4,21 & 4,34 \\
\hline $\mathrm{TF}$ & 4,22 & 4,33 & 4,27 & 4,08 & 4,47 & 4,27 \\
\hline Average & 4,40 & 4,25 & -- & 4,33 & 4,29 & -- \\
\hline $\mathrm{CM}$ & \multicolumn{2}{|c|}{3,61} & -- & \multicolumn{2}{|c|}{3,71} & -- \\
\hline CV $(\%)$ & \multicolumn{3}{|c|}{10,27} & \multicolumn{3}{|c|}{14,89} \\
\hline
\end{tabular}


continuation

\begin{tabular}{|c|c|c|c|c|c|c|}
\hline \multicolumn{7}{|c|}{$\mathrm{pH}$} \\
\hline $\mathrm{CF}$ & $4,14+$ & $4,21+$ & 4,22 & 4,01 & 3,89 & 3,95 \\
\hline $\mathrm{TF}$ & 3,66 & 3,96 & 3,81 & 3,80 & 3,99 & 3,89 \\
\hline Average & 3,90 & 4,13 & -- & 3,90 & 3,94 & -- \\
\hline $\mathrm{CM}$ & \multicolumn{2}{|c|}{3,54} & -- & \multicolumn{2}{|c|}{3,55} & -- \\
\hline CV $(\%)$ & \multicolumn{3}{|c|}{3,96} & \multicolumn{3}{|c|}{3,88} \\
\hline \multicolumn{7}{|c|}{ IVDDM } \\
\hline $\mathrm{CF}$ & $57,07+$ & $59,13+$ & 58,1 & 52,55 & 52,39 & 52,69 \\
\hline TF & 56,83 & 54,37 & 55,60 & 55,62 & 53,21 & 54,41 \\
\hline Average & 56,95 & 56,75 & -- & 54,08 & 52,80 & -- \\
\hline $\mathrm{CM}$ & \multicolumn{2}{|c|}{53,43} & -- & \multicolumn{2}{|c|}{55,28} & -- \\
\hline CV (\%) & \multicolumn{3}{|c|}{6,12} & \multicolumn{3}{|c|}{6,38} \\
\hline
\end{tabular}

CM - corn monoculture. + or - stand respectively for means above or below the comparative control (CM) by the Dunnett's test $(\mathrm{p}<0.05) .{ }^{1 /}$ Trial 1: Intercropping under single row system alternating between RR corn and RR soybean. Trial 2: Intercropping under a system of double row of RR corn alternated with one RR soybean row.

For $\mathrm{pH}$, no significant interaction was detected between soybean variety and fertilization method (Table 4). However, for plant arrangement used in trial 1 , when fertilization was done only in corn rows, higher $\mathrm{pH}$ values were observed regardless of soybean variety. Despite that, all $\mathrm{pH}$ values were within the adequate range (from 3.8 to 4.2). It is known that high $\mathrm{pH}$ values in silage indicate increased production of butyric acid and acetic acid, thus resulting in undesirable fermentations (VAN SOEST, 1994).

In both trials, similar behavior was observed for IVDDM (Table 4). Soybeans present high digestibility rate, which improves the digestive profile of intercropped silage (VASCONCELOS et al., 2016). Such improvement could be observed in trial 1 , where silages from intercropped plants obtained higher values than the control with only corn.
For MM and DM contents, significant interactions were found between fertilizer form and soybean variety but only for single-corn-row arrangements (trial 1). Regarding DM, contents decreased for treatments with fertilization only in corn rows and use of late-cycle soybean variety, as well as for those with total area fertilization and medium-cycle variety. Overall, the intercropping of soybeans and corn promoted no increases in total forage yield but increased MM content in the silage produced. When comparing intercropping and single-corn silages, increases in MM contents were observed for intercropping treatment in the singlerow system, total area fertilization and for the late-cycle soybeans. Similarly, in the double-cornrow system with fertilization in corn rows, when intercropping with medium-cycle soybean variety were observed increases in MM content in relation to single-corn silages (Table 5). 
Table 5. Contents of mineral material (MM), dry matter (DM), crude protein (CP), ether extract (EE) and total digestible nutrients (TDN) of silage from soybean and corn intercropping and from corn monoculture as a function of treatments: CF - fertilization only in corn rows; TF - fertilization in total area; MCV - medium-cycle soybean variety; LCV - late-cycle soybean variety in both trials.

\begin{tabular}{|c|c|c|c|c|c|c|}
\hline \multirow[t]{2}{*}{ Treatments } & \multicolumn{3}{|c|}{${ }^{1 /}$ Trial 1} & \multicolumn{3}{|c|}{ Trial 2} \\
\hline & $\mathrm{MCV}$ & LCV & Average & $\mathrm{MCV}$ & $\mathrm{LCV}$ & Average \\
\hline \multicolumn{7}{|c|}{ MM \% } \\
\hline $\mathrm{CF}$ & $4,41 \mathrm{aA}$ & $3,12 \mathrm{bB}$ & 3,76 & $4,75+$ & 4,29 & 4,52 \\
\hline $\mathrm{TF}$ & $4,10 \mathrm{aB}$ & $5,02 \mathrm{aA}+$ & 4,56 & 4,26 & 4,25 & 4,25 \\
\hline Average & 4,25 & 4,07 & -- & 4,50 & 4,27 & -- \\
\hline $\mathrm{CM}$ & \multicolumn{2}{|c|}{3,90} & -- & \multicolumn{2}{|c|}{3,98} & -- \\
\hline CV $(\%)$ & \multicolumn{3}{|c|}{11,50} & \multicolumn{3}{|c|}{8,62} \\
\hline \multicolumn{7}{|c|}{ DM \% } \\
\hline $\mathrm{CF}$ & $23,74 \mathrm{bB}-$ & $29,42 \mathrm{aA}-$ & 26,58 & $27,23-$ & $28,89-$ & 28,06 \\
\hline $\mathrm{TF}$ & $29,16 \mathrm{aA}-$ & $29,97 \mathrm{aA}-$ & 29,56 & $31,42-$ & $29,91-$ & 30,66 \\
\hline Average & 26,45 & 29,69 & -- & 29,32 & 29,40 & -- \\
\hline $\mathrm{CM}$ & \multicolumn{2}{|c|}{35,87} & -- & \multicolumn{2}{|c|}{35,93} & -- \\
\hline CV $(\%)$ & \multicolumn{3}{|c|}{7,51} & \multicolumn{3}{|c|}{7,50} \\
\hline \multicolumn{7}{|c|}{$\mathrm{CP} \%$} \\
\hline $\mathrm{CF}$ & 8,96 & 7,97 & 8,46 & $9,51+$ & $9,60+$ & 9,55 \\
\hline $\mathrm{TF}$ & 9,07 & $9,51+$ & 9,29 & $9,59+$ & $9,30+$ & 9,44 \\
\hline Average & 9,01 & 8,74 & -- & 9,55 & 9,45 & -- \\
\hline $\mathrm{CM}$ & \multicolumn{2}{|c|}{7,50} & -- & \multicolumn{2}{|c|}{7,07} & -- \\
\hline CV $(\%)$ & \multicolumn{3}{|c|}{10,29} & \multicolumn{3}{|c|}{3,47} \\
\hline \multicolumn{7}{|c|}{ EE \% } \\
\hline $\mathrm{CF}$ & 4,93 & $5,05+$ & 4,99 & 3,76 & 4,22 & 3,99 \\
\hline $\mathrm{TF}$ & $5,16+$ & 4,27 & 4,71 & 4,02 & $5,19+$ & 4,60 \\
\hline Average & 5,04 & 4,66 & -- & 3,89 & 4,70 & -- \\
\hline $\mathrm{CM}$ & \multicolumn{2}{|c|}{2,09} & -- & \multicolumn{2}{|c|}{2,26} & -- \\
\hline $\mathrm{CV}(\%)$ & \multicolumn{3}{|c|}{8,09} & \multicolumn{3}{|c|}{7,14} \\
\hline \multicolumn{7}{|c|}{ TDN (\%) } \\
\hline $\mathrm{CF}$ & 69,97 & $70,49+$ & 70,23 & $69,69+$ & 69,02 & 69,35 \\
\hline $\mathrm{TF}$ & $70,74+$ & $70,88+$ & 70,81 & 69,36 & $69,76+$ & 69,56 \\
\hline Average & 70,35 & 70,68 & -- & 69,52 & 69,39 & -- \\
\hline $\mathrm{CM}$ & \multicolumn{2}{|c|}{68,11} & -- & \multicolumn{2}{|c|}{67,12} & -- \\
\hline CV $(\%)$ & \multicolumn{3}{|c|}{15,83} & \multicolumn{3}{|c|}{13,05} \\
\hline
\end{tabular}

$\mathrm{CM}$ - corn monoculture. + or - stand respectively for means above or below the comparative control (CM) by the Dunnett's test $(\mathrm{p}<0.05)$. Means followed by different lowercase letters within columns and uppercase letters within rows are statistically different by the Tukey's test $(\mathrm{p}<0.05) .{ }^{1 /}$ Trial 1 : Intercropping under single row system alternating between RR corn and RR soybean. Trial 2: Intercropping under a system of double row of RR corn alternated with one RR soybean row.

Exclusive corn silages presented higher DM contents than did intercropping silages in both trials (Table 5). In trial 1, a significant interaction between fertilization forms and soybean varieties was observed, with lower values for intercropping with corn-row fertilization and medium-cycle 
soybean variety. When testing corn intercropped with different soybean varieties and in varied plant arrangements plus corn monoculture, Lempp et al. (2000) found no significant differences in DM contents among treatments, with averages of 27.02 and $26.87 \%$ for the first and second year of evaluation, respectively. Nussio et al. (2001) stated that good silages should have around 30\% DM. The lower values observed in our study may be related to the high humidity of soybean plants at harvest, as well as to losses during fermentation such as GL and EL.

As soybean is a protein-rich oilseed crop, $\mathrm{CP}$ contents were increased in intercropped treatments compared to corn monoculture (Table 5). Particularly, in trial 1 , the highest content of CP was observed for corn intercropped with latecycle soybeans with sowing fertilization carried out only in corn rows. Yet, in trial 2, CP contents were higher in all intercropping treatments (Table 5). All treatments had CP contents above 7\%, considered the minimum limit for the proper growth of rumen bacteria. Contents of CP in DM levels below 7\% had a negative effect on silage intake and nutrient digestibility due to a deficiency in rumen nitrogen. Based on this criterion, all silages produced in our experiments may be considered suitable since CP contents ranged from 7.07 to $9.60 \%$ (Table 5). Increases in CP contents of corn and soybean silages were also reported by Fichtner et al. (1989), Obeid et al. (1992), Eichelberger et al. (1997), and Lempp et al. (2000). Thus, soybean intercropping with corn silage can reduce protein supplementation and hence costs of purchasing commercial concentrates (ANDRADE JÚNIOR; MARTINS, 2013).

Furthermore, soybean addition into silage increased EE contents in intercropped treatments, mainly in those intercropping corn and mediumcycle soybeans with total area fertilization, and also in corn intercropped with late-cycle variety with fertilization in corn row only (trial 1) and with late-cycle variety and total area fertilization (trial 2) (Table 5). High EE contents in soybeans in monoculture may reach $23 \%$ in DM due to higher seed oil contents (GOBETTI et al., 2011); however, when intercropped with corn, such contents decreased, showing values between 3.76 and $5.19 \%$. In silage from corn monoculture, EE contents were similar to those found by Pinto et al. (2010), which were between 2.0 and $2.20 \%$.

Total digestible nutrients (TDN) play a role as indicator of food energy and its determination in silages is crucial for diet balancing. According to Neumann et al. (2014), good quality silages must have above $65 \%$ TDN. All treatments in both trials and including corn monoculture had silages with TDN values above that (Table 5). In trial 1, except for corn intercropped with medium-cycle soybeans fertilized only in corn rows, all the other treatments showed TDN values above that of control. Meanwhile, in trial 2, TDN values were statistically superior for silages from corn intercropped with medium-cycle soybeans and fertilization only in corn rows, as well as for silages of corn intercropped with late-cycle soybeans and fertilization in total area (Table 5).

\section{Conclusions}

The silage yield was similar among corn-soybean intercropping and the corn monoculture, regardless of the plants arrangements, soybean varieties and sowing fertilization. However, the soybean addition, regardless of treatments, contributes to the $\mathrm{ADF}$ and cellulose contents reduction; and increase the CP, TDN and hemicellulose contents, according to plant arrangements soybean varieties and sowing fertilization.

Although it has improved certain bromatological parameters, silage from corn-soybean intercropping contributes to the increased losses during the fermentation process by reducing the dry matter content of the ensiled mass. For this reason, more research is needed to increased dry matter in mixed silage between corn and soybean. 


\section{Acknowledgments}

To the IF Goiano (Federal Institute of Education, Science and Techonology Goiano) by the financial support provided.

\section{References}

ANDRADE JÚNIOR, P. P.; MARTINS, C. A. Biodiesel and its strategic role in the Brazilian energy matrix: a literature review. Engineering Research, Taubaté, v. 5, n. 1, p. 1-17, 2013. DOI: 10.32426/engresv5n1-001

ASSOCIATION OF OFFICIAL ANALYTICAL CHEMISTS - AOAC. Official methods of analysis. $15^{\text {th }}$ ed. Arlington, VA: AOAC International, 1990.

BALBINO, L. C.; CORDEIRO, L. A. M.; SILVA, V. P.; MORAES, A.; MARTÍNEZ, G. B.; ALVARENGA, R. C.; KICHEL, A. N.; FONTANELI, R. S.; SANTOS, H. P.; FRANCHINI, J. C.; GALERANI, P. R. Evolução tecnológica e arranjos produtivos de sistemas de integração lavoura-pecuária-floresta no Brasil. Pesquisa Agropecuária Brasileira, Brasília, v. 46, n. 10, p. 1-12, 2011. DOI: 10.1590/S0100-204X2011001000001

BARCELLOS, A. D. O.; RAMOS, A. K. B.; VILELA, L.; MARTHA JUNIOR, G. B. Sustentabilidade da produção animal baseada em pastagens consorciadas e no emprego de leguminosas exclusivas, na forma de banco de proteína, nos trópicos brasileiros. Revista Brasileira de Zootecnia, Viçosa, MG, v. 37, p. 51-67, 2008. Suplemento Especial. DOI: $10.1590 / \mathrm{S} 1516-35982008001300008$

BOLSEN, K. K.; ASHBELL, G.; WEINBERG, Z. G. Silage fermentation and silage additives-review. AsianAustralasian Journal Animal Science, Bet Dagan, v. 9, n. 5, p. 483-493, 1996. DOI: 10.5713/ajas.1996.483

CARVALHO, E. R.; OLIVEIRA, J. A.; VILELA REIS, L.; FERREIRA, F. T. Mn foliar sobre a qualidade sanitária e lignina de sementes de soja convencional e resistente ao glifosato. Revista Ciência Agronômica, Fortaleza, v. 46, n. 1, p. 135-143, 2015. DOI: v46n1/0045-6888rca-46-01-0135

CORREIA, N.; DURIGAN, C. J. Controle de plantas daninhas na cultura de soja resistente ao glyphosate. Bragantia, Campinas, v. 69, n. 2, p. 319-327, 2010. DOI: 10.1590/S0006-87052010000200009

DEMINICIS, B.; VIEIRA, H. D.; JARDIM, J. G.; ARAÚJO, S. A. C.; CHAMBELA NETO, A.; CORRÊA, O.; LIMA, E. D. Silagem de milho-características agronômicas e considerações. Revista Electrónica de Veterinaria, Málaga, v. 10, n. 1, p. 1-18, 2009. Disponível em: http://www.redalyc.org/articulo.oa?id= 63617120003. Acesso em: 2 fev. 2018

DOMINGUES, M. S.; BERMANN, C. O arco de desflorestamento na Amazônia: da pecuária à soja. Ambiente \& sociedade, São Paulo, v. 15, n. 2, p. 1-22, 2012. DOI: $10.1590 / \mathrm{S} 1414-753 X 2012000200002$

EICHELBERGER, L.; SIEWERDT, L.; SILVEIRA JÚNIOR, P. Efeitos da inclusão de níveis crescentes de forragem de soja e uso de inoculante na qualidade da silagem de milho. Revista Brasileira de Zootecnia, Viçosa, MG, v. 26, n. 5, p. 867-874, 1997.

EMPRESA BRASILEIRA DE PESQUISA AGROPECUÁRIA - EMBRAPA. Serviço nacional de levantamento e conservação de solo. Manual de métodos de análise de solo. 2. ed. Rio de Janeiro: Centro Nacional de Pesquisa de Solos, 1997. 212 p.

FICHTNER, S. S.; ELEUTÉRIO, A.; MONTEIRO, P. M. Efeito da associação milho-soja na produção e composição química da silagem. Anais da Escola de Agronomia e Veterinária, Goiânia, v. 19, n. 1, p. 87-96, 1989. DOI:

GOBETTI, S. T. C.; NEUMANN, M.; OLIVEIRA, M. R.; OLIBONI, R. Produção e utilização da silagem de planta inteira de soja (Glycine max) para ruminantes. Ambiência, Guarapuava, v. 7, n. 3, p. 603-616, 2011. DOI: 10.5777/ambiencia. 2011.03.02rb

GOMES, J. D.; PUTRINO, S. M.; GROSSKLAUS, C.; UTIYAMA, C. E.; LOTUFO OETTING, L.; SOUZA, L. W. O.; LIMA, C. G. Efeitos do incremento de fibra dietética sobre a digestibilidade, desempenho e características de carcaça: I. suínos em crescimento e terminação. Semina: Ciências Agrárias, Londrina, v. 28, n. 3, p. 483-492, 2007. DOI: $10.5433 / 1679-0359.2007 \mathrm{v} 28 \mathrm{n} 3 \mathrm{p} 483$

JOBIM, C. C.; NUSSIO, L. G.; REIS, R. A.; SCHMIDT, P. Avanços metodológicos na avaliação da qualidade da forragem conservada. Revista Brasileira de Zootecnia, Viçosa, MG, v. 36, p. 101-119, 2007. Suplemento Especial. DOI: 10.1590/S1516-35982007001000013

LEMPP, B.; MORAIS, M. G.; SOUZA, L. C. F. Produção de milho em cultivo exclusivo ou consorciado com soja e qualidade de suas silagens. Arquivo Brasileiro Medicina Veterinária e Zootecnia, Belo Horizonte, v. 52, n. 3, p. 243249, 2000. DOI: 10.1590/S0102-09352000000300013

MERTENS, D. R. Gravimetric determination of amylasetreated neutral detergent fiber in feeds with refluxing in beaker or crucibles: collaborative study. Journal of AOAC International, Rockville, v. 85, n. 6, p. 1217-1240, 2002. DOI: 
MORAES, G. J.; COSTA, C.; MEIRELlES, P. R.; OLIVEIRA, K.; FACTORI, M. A.; ROSALES, L. A.; SANTOS, T. A. B. Produtividade e valor nutritivo das plantas de milho de textura dentada ou dura em três estádios de colheita para silagem. Boletim de Indústria Animal, Nova Odessa, v. 65, n. 2, p. 155-166, 2008. Disponível em: http://iz.agricultura.sp.gov.br/bia/index. php/bia/article/view/1135. Acessado em: 2 fev. 2018. DOI:

NEUMANN, M.; FIGUEIRA JUNIOR, D. N.; BUMBIERIS JUNIOR, V. H.; UENO, R. K.; LEÃO, G. F. M. Ensilagem: estratégias visando maior produção de leite. In: SIMPÓSIO BRASILEIRO DE RUMINANTES LEITEIROS, UDILEITE, 1., 2014, Uberlândia. Anais... Uberlândia: Universidade Federal de Uberlândia, 2014. p. 130-166.

NUSSIO, L. G.; CAMPOS, F. P.; DIAS, F. N. Importância da qualidade da porção vegetativa no valor alimentício da silagem de milho. In: SIMPÓSIO SOBRE PRODUÇÃO E UTILIZAÇÃO DE FORRAGENS CONSERVADAS, 2001, Maringá. Anais... Maringá: Universidade Estadual de Maringá, 2001. p. 127-145.

OBEID, J. A.; GOMIDE, J. A.; CRUZ, M. E. Silagem consorciada de milho (Zea mays) com leguminosas: produção e composição bromatológica. Revista Brasileira de Zootecnia, Viçosa, MG, v. 21, n. 1, p. 3338, 1992. DOI:

PARIZ, C. M.; ANDREOTTI, M.; AZENHA, M. V.; BERGAMASCHINE, A. F.; MELLO, L. M. M.; RONALDO, R. C. Produtividade de grãos de milho e massa seca de braquiárias em consórcio no sistema de integração lavoura-pecuária. Ciência Rural, Santa Maria, v. 41, n. 5, p. $875-882$, 2011. DOI: $10.1590 / \mathrm{S} 0103-$ 84782011000500023

PINTO, A. P.; LANÇANOVA, J. A. C.; LUGÃO, S. M. B.; ROQUE, A. P.; ABRAHÃO, J. J. S.; OLIVEIRA, J. S.; LEME, M. C. J.; MIZUBUTI, I. Y. Avaliação de doze cultivares de milho (Zea mays L.) para silagem. Semina: Ciências Agrárias, Londrina, v. 31, n. 4, p. 1071-1078, 2010. DOI: $10.5433 / 1679-0359.2010 v 31 n 4 p 1071$

SANTOS, E.; ZANINE, A. M.; DANTAS, P. A. S.; DOREA, J. R. R.; SILVA, T. C.; PEREIRA, O. G. LANA, R. P. Composição bromatológica, perdas e perfil fermentativo de silagens de capimelefante com níveis de jaca desidratada. Revista Brasileira de Saúde e Produção Animal, Salvador, v. 9, n. 1, p. 71-80, 2008.

SILVA, F.A. S.; AZEVEDO, C.A. V. The assistat software version 7.7 and its use in the analysis of experimental data. African Journal of Agricultural Research, v. 11, n. 39, p. 3733-3740, 2016. DOI: 10.5897/AJAR2016.11522

SILVA, M. D.; CARNEIRO, M. S.; PINTO, A. P.; POMPEU, R. C. F. F.; SILVA, D. S.; COUTINHO, M. J. F.; FONTENELE, R. M. Evaluation of the chemical composition of woody forage silages of the Brazilian semiarid. Semina: Ciências Agrárias, Londrina, v. 36, n. 1, p. 571-578, 2015. DOI: 10.5433/1679-0359.2015v36n1p571

SOUSA, D. M. G.; LOBATO, E. Cerrado: correção do solo e adubação. 2. ed. Brasília: EMBRAPA Informação Tecnológica, 2004. 416 p.

TILLEY, J. M. A.; TERRY, R. A. A two stages technique for the in vitro digestion of forage crope. Journal of the British Grassland Society, Hoboken, v. 18, n. 1, p. 104111, 1963. DOI: 10.1111/j.1365-2494.1963.tb00335.x

VAN SOEST, P. Nutritional ecology of the ruminant. $2^{\text {th }}$ ed. Ithaca: Cornell University, 1994. 476 p.

VAN SOEST, P. J.; ROBERTSON, J. B. Analysis of forages and fibrous foods. Ithaca: Cornell University, 1985. $202 \mathrm{p}$.

VASCONCELOS, A. M. D.; DIAS, M.; NASCIMENTO, V. A.; ROGÉRIO, M. C. P.; FAÇANHA, D. A. E. Ruminal degradability and intestinal digestibility of raw and roasted soy beans in dairy cows. Revista Brasileira de Saúde e Produção Animal, Salvador, v. 17, n. 4, p. 744752, 2016. DOI: 10.1590/s1519-99402016000400017

VIEIRA, V. C.; MORO, V.; FARINACIO, D.; MARTIN, T. N.; MENEZES, L. F. G. Caracterização da silagem de milho, produzida em propriedades rurais do sudoeste do Paraná. Revista Ceres, Viçosa, MG, v. 58, n. 4, p. 462469, 2011. DOI: 10.1590/S0034-737X2011000400009

ZIMMER, A.; MACEDO, M.; KICHEL, A.; ALMEIDA, R. D. Degradação, recuperação e renovação de pastagens. Campo Grande: EMBRAPA Gado de Corte, 2012. 42 p. (Documentos, 189). 
